\title{
The Research Library and the Scholar
}

W HAT DO SCHOLARS THINK of the research library and research librarians? Librarians have written extensively of how useful libraries are to scholarship and research. Do scholars agree with them? Are libraries essential for national survival, for supporting the economic life of the nation, and for providing the sources of data necessary for a trained youth and informed public?1 Howard Mumford Jones, professor of English, Harvard University, states that the primary aim of the research library is to collect, enrich, and preserve records of intellectual achievement from every culture and all time. ${ }^{2}$ Richard D. Altick, professor of English, Ohio State University, asserts that the whole edifice of modern scholarship rests upon the foundation of research libraries. ${ }^{3}$

Other scholars have commented on research libraries. It is the purpose of this review to examine a selected group of such views published since 1945. This date has been chosen because since World War II the demands upon research libraries have increased substantially. What do these views tell us of the wants and needs of scholars? How does the problem of library growth appear to them? What do they think of current practices in cataloging and classification? What do they expect in terms of research assistance from librarians? What do they consider to be the attributes of the ideal

\footnotetext{
1 Kurt Peiser, "The Research Library in Contemporary Society," in Pennsylvania. University. Library. Changing Patterns of Scholarship and the Future of Research Libraries (Philadelphia: 1951), p.54.

2 "Opportunities and Support for College and University Libraries," CRL, XIV (1953), 9-21.

3 "The Scholar's Paradise," $C R L$ XV (1954), 382.
}

Mr. Birnbaum is Chief Circulation Librarian, Brooklyn College Library. librarian? What are their ideas in respect to the future of research libraries? These questions provide a framework for the discussions by faculty members, researchers, and directors of research.

Before entering directly into these discussions, however, it may be useful to describe briefly "the research library," "scholar," and "scholarship."

Three types of scholarly or research libraries may be identified: (1) special libraries serving a small area of learning; (2) university libraries which undertake to cover the whole field of scholarship; ${ }^{4}$ and (3) libraries which fall somewhere in between, such as "special collectionsi' made up largely of rare and out-of-print books dealing with the same or related subjects. 5 Variations in aims and purposes of each type of research library occur and influence the collections.

Conyers Read, professor of history, University of Pennsylvania, defines research libraries as institutions designed to assist those engaged in extending the boundaries of knowledge, ${ }^{6}$ and E. H. Wilkins, Harvard University, sees the research library in a university as the custodian of the world's actual knowledge and the reservoir of its potential knowledge. ${ }^{7}$

Webster's New Collegiate Dictionary defines a scholar as one who has engaged in advanced study and has acquired knowledge in some special field. ${ }^{8}$ A scholar also may be defined as an individual

\footnotetext{
"Conyers Read, "Libraries and Scholarship," in Pennsylvania. University. Library. Op. cit., p.98. Scholar," in Chicago. University. Graduate Library School. Librarians, Scholars and Booksellers at Midcentury (Chicago: 1953), p.49.

Loc. cit.

" "The University Library and Scholarship," Harvard Library Bulletin, IV (1950), 16.

8 Webster's New Collegiate Dictionary, 5th ed., 1948, p. 889 .
} 
who is engaged in extending the boundaries of knowledge, who develops new or syntheses of knowledge, and who needs and uses research libraries to attain his goal.

A narrower definition of a scholar, by Louis Gottschalk, professor of modern history, University of Chicago, is that he is an investigator whose research material is to be found in printed sources that are relatively rare or out-of-print; hence the investigator who, for the most part, is engaged in either historical or humanistic research. This definition is not meant to exclude the natural scientist concerned with the study of the history of his science from rare and out-of-print books, or the social scientist concerned with the more remote historical development of either the thought or the institutions that fall within his field. ${ }^{9}$

Scholarship is defined by Merle E. Curti, professor of history, University of Wisconsin, as high competence in a delimited field of conscious and sustained inquiry for related facts, valid generalizations, and workable truths. ${ }^{10}$

The Scholar's Wants and Needs. The literature reveals that the wants and needs of scholars in libraries are related to subject interests. The statements selected, therefore, have been separated into two groups, those from humanists and social scientists, and those from natural scientists.

Albert C. Baugh, professor of English, University of Pennsylvania, points out that for the humanists and social scientists, the research library has to be the laboratory as well as the research tool, providing a key to the results of previous scholarship. Not only are current materials needed, but also original texts and documents of all kinds. He recognizes, however, that the ideal of completeness is impossible in all fields, and

\footnotetext{
- Loc. cit.

${ }_{10}$ American Scholarship in the Twentieth Century (Cambridge, Mass.: Harvard University Press, 1953), pp.1-2.
}

that some selectivity is inevitable. Baugh suggests that the available funds be distributed among four categories: (1) basic tools such as bibliographies, works of reference, and the important serials which should be purchased no matter what else the library does; (2) the most important books in most fields; (3) special collections in those fields where special work is being done by the faculty; and, (4) a luxury sum for modest additions to collectors' items, rarities, and manuscripts. ${ }^{11}$

James D. Hart, professor of English, University of California at Berkeley, concurring, notes that if a university is to be maintained as a scholarly institution, its library must not only possess a vast basic collection of research materials, but it must each year buy the many published books and journals which represent its appropriate coverage of the world's knowledge put into print. He and John D. Millett, president, Miami University, Oxford, Ohio, agree however, that a ceiling can be placed on an undergraduate book collection, because a library with more than a quarter million volumes seems to present college students with almost as many problems as solutions. On the other hand, Hart believes that no simple limits can be put on the library of an educational institution offering strong graduate programs in a large number of subjects. ${ }^{12}$

According to Crane Brinton, professor of ancient and modern history, Harvard University, and John F. McDermott, associate professor of English, Washington University, the humanist and social scientist also will demand obscure materials and materials that in the past did not attain the dignity of "literature," such as old Sears, Roebuck catalogs, out-

\footnotetext{
11 "The Balance of Conflicting Interests in the Building of Collections. Discussion," in Pennsylvania. University. Library. $O P$. cit., pp.80, 82 .

12 Hart, "What a Scholar Expects of Acquisitions," in Edwin E. Williams, ed. Problems and Prospects of the Research Litrary (New Brunswick, N.J.: Scarethe Research 1955) crow Press, 1955), p.59; Millett, Financing Higher Education in the United States
University Press, 1952), p.123.
} 
of-date textbooks, dime novels, and other fugitive writings. These materials, Brinton believes, are needed to satisfy the demand for what is called "the new history and the new criticism," and are an attempt to get as great a range of concrete facts as possible on which to test concepts, hypotheses, and ideas about human behavior. ${ }^{13}$

Meeting the demands of the natural scientists is no easier task for a research library than meeting the needs of the humanists and social scientists. While natural scientists will want materials that cover the historical aspects of their particular field, Philip M. Morse, professor of physics, Massachusetts Institute of Technology, finds that the main emphasis is on current literature. Contrary to the humanists and social scientists, he feels that the research physicist's library, for instance, is much better if it does not contain books that are very rarely used.14 According to Fred L. Pundsack, senior research chemist, Johns-Manville Corporation, the user of a scientific library expects to find a comprehensive file of periodicals relating to his field of interest, as well as a relatively extensive holding of reference books and texts. ${ }^{15}$

A final comment equally applicable to all groups is made by Altick. He protests the practice of withholding such materials as manuscripts from the use of all but some privileged person who has successfully asserted his right to a monopoly. Altick agrees that a faculty member who has materially aided in the acquisition of a certain collection is entitled to first use, provided that he does so within a reasonable time. After the expiration of that time, the collection should be thrown open with as few restrictions as possible to all scholars. ${ }^{16}$

13 Brinton, "Patterns of Research and Changing Library Needs," in Pennsylvania. University. Library. Op. cit., p.10; McDermott, "A University Professor Appraises the University Library," Missouri Library
Association Quarterly, XII (1951), 231. Readers," in Williams, ed. Op. cit., p.78.

15 "What the User Expects from the Library," Specinl Libraries, XL (1955), 163.

${ }_{10} O p$. cit., p.381.
Library Growth. It is perhaps natural for the scholar to desire and demand all that he thinks he needs for his research. However, Hart recognizes that there must be limitations, despite the necessity for growth of the library if his university is not to stagnate. But, Hart also realizes that while the making of books for libraries is endless, the balancing of books in the comptroller's office has a definite end. His suggestions for controlling growth are an increased move towards cooperative storage libraries and the use of more microreproductions. ${ }^{17}$

Altick recognizes that the modern university library fulfills a highly complex purpose and he views it as inescapable that the book-stock must be distributed in a number of places in addition to the main stack. His hope is that decentralization be minimized. On the other hand, if the books do have to be decentralized and in some instances stored, he pleads that their current whereabouts be clearly noted in the public catalog. ${ }^{18}$

Millett blames the librarians for the growth of research libraries in universities. He states that librarians hesitate to throw anything away because they always fear that the book they discard will be the one someone wants next month, and, he says, they are always chagrined when they cannot at once produce what is wanted. ${ }^{19}$ Later comments by Millett indicate that he was more concerned with college, rather than university, libraries.

A primary problem of the researcher in science is keeping up with the literature. To find a solution to this problem is the central concern of suggestions.

Ralph E. Cleland, department of botany, Indiana University, and Mildred C. Rebstock, research department, Parke, Davis \& Company, Detroit, suggest that scientific journals, instead of publishing full-length papers, as is current practice, should present concise yet

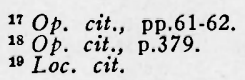


comprehensive abstracts of the author's work, written by the author, and then make the entire paper available on microcard or microfilm. This practice, they believe, would make for publishing economy. Rebstock adds that another course which many scientific researchers believe would help control the volume of the scientific literature involves the use of more restraint on the part of authors and editors alike in deciding what is really worth publishing. There has been a tendency, she says, particularly in some academic circles, to evaluate a person by the number of papers he publishes rather than by the quality of his work. ${ }^{20}$

Another suggestion for coping with the vast amount of scientific literature is advanced by Watson Davis, director of Science Service. Instead of traditional publication, he recommends auxiliary publication through the deposit of the manuscript in a central place, to be numbered and abstracted without cost by the central agency. The central agency could then send out film copies of any deposited manuscript, as requested, through the abstracting service. This idea, he points out, is already in operation in the Bibliography of Scientific and Industrial Reports, prepared by the Office of the Publication Board, Department of Commerce. ${ }^{21}$

The Scholar's Viewpoint on the Technical Services. The area of technical services is one with which scholars are generally not too familiar. They should not be expected to be, although some understanding on their part of technical procedures would lead to increased understanding of what services a research library can provide.

One of the questions raised by scholars is who should choose the books to be acquired, the scholar or the librarian.

${ }^{20}$ Cleland, "The Use of Material," Science CXXI (1955), 519; Rebstock, "Chemist, the Library and the Laboratory," Special Libraries, XLVII (1956), 19, 20. ${ }^{21}$ William H. Carlson, "Research Worker and the Library," $C R L$, VII (1946), 296.
R. M. Hartwell, head of the School of Humanities and Social Sciences, New South Wales University of Technology, believes that in universities the choice is usually the prerogative of the scholar, even though the librarian argues that he is the more impartial buyer and that too often when the scholar directs the buying, he buys only to suit his individual research. ${ }^{22}$ Hart suggests increased specialization in acquisitions and increased attention to interlibrary loans. $\mathrm{He}$ reasons that these two activities might help keep down the need for duplication of books in one research library after another. ${ }^{23}$

Comments by scholars on catalogs, cataloging, and classification point up the difficulty librarians have in coping with these problems to everyone's satisfaction, especially since there is a divergence of opinion between the humanists and social scientists on the one hand and the natural scientists on the other.

Hartwell, speaking for the humanists and social scientists, recognizes that the important link between the reader and the books of a library is the catalog, and that the catalog is of great use both to the scholar and to the general reader. For the general reader, however, he believes the catalog need be little more than a finding list. For the scholar, on the other hand, it should be a reference tool in its own right. To avoid delay and duplication in cataloging, he supports centralized cataloging programs. ${ }^{24}$ McDermott admits that books must be cataloged for convenience of storing and finding, but he complains that sometimes rules are neither reasonable nor applicable. The fact is, he says, that cataloging appears to be one of the great mysteries to the non-librarian. ${ }^{25}$

Read claims that there is a lack of good comprehensive subject catalogs. ${ }^{26}$

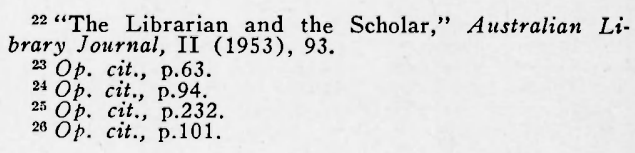


William B. Hamilton, professor of history, Duke University, in agreement with Read, states that the tremendous range of the social scientist and the humanist is sufficient justification for plenty of subject cards in the catalog. This seems to him to be the only answer to refute the view held by some extremists that a scholar is a specialist who already knows the literature of his field or can readily explore it through bibliographies and indexes. In his opinion, the scholar must place heavy dependence on the subject catalog in research libraries. For this reason, Hamilton expects and hopes that a catalog constitutes an exhaustive bibliography on a subject; that it opens up most subjects to the uninitiated; that it pinpoints for the scholar the works and keys that will lead to a thorough exploration of his subjects; and that the catalog lists the holdings of the library under headings currently in use with both a little ingenuity and a little knowledge of the conventions of subject headings. Finally, documents ought to take their place in the subject catalog. ${ }^{27}$ Allen T. Hazen, professor of English, School of Library Service, Columbia University, comments that it is his belief that the researcher approaches the subject catalog by cutting across the lines necessarily laid down by the subject cataloger. He suggests that the cataloger is unable to foresee all possible paths that may be taken by a scholar. ${ }^{28}$

Joseph S. Fruton, professor of biochemistry, Yale University, representing the point of view of natural scientists, makes some remarks concerning catalogs and cataloging that seem to be contrary to those of humanists and social scientists. He states that it is often said that library subject headings may be helpful to a person working in a field other than his own. He asks us to suppose that he

\footnotetext{
${ }^{27}$ "What Scholars Expect of Library Cataloguing," in Williams, ed. $O p$. cit., pp.66, 67.

${ }_{28}$ "Reflections and Observations on Subject Anal ysis," in Maurice F. Tauber, ed. The Subject Anal. ysis of Library Materials (New York: Columbia University, School of Library Service, 1953), p.195.
}

requires material in the field of geology. In his judgment the wisest course for him to follow would be to ask his colleagues in the geology department for help rather than tackle the subject cards for geology in the library catalog. For this reason he does not think an elab. orate system of subject cards can be justified on the ground that occasional material outside his area of specialization may be required. He believes that preparing and circulating classified lists of new accessions would help more than making subject entries for card catalogs.

Fruton also comments on descriptive cataloging. To him, the card catalog is of secondary importance, and is consulted only as a finding list to help locate items which cannot readily be found on the shelves. Fruton believes that scientists generally would like all data on catalog cards to be accurate and reliable, but he would be content with mere identification. He finds that catalogers often set up technical headings which are difficult for library users to locate. His experience has been that entries under personal names are not hard to find, but he has trouble with items listed under the names of institutions, especially government agencies. And, finally, Fruton suggests that the filing rules should be as non-technical as possible so that entries can be easily found. ${ }^{29}$

In the area of the technical services the scientists are the most vocal about classification. Fruton states flatly that the fact there are so many classification systems suggests that there is something wrong with all of them. He feels that one of the major difficulties in the organizing of current scientific works is the impossibility of accommodating a necessarily rigid classification scheme to major changes in the trend of scientific research and emergence of new scientific disciplines. ${ }^{30}$ Morse expresses his doubts concerning classification systems by stating that any

20 "What Scholars Expect of Library Cataloguing," in Williams, ed. $O p$. cit., pp.73-75.

so Ibid., pp.61, 72 . 
system attempting to classify things on a linear basis - one-dimensionally_cannot succeed much better than the present classifications do. ${ }^{31}$

The scientist Vannevar Bush recognizes that the investigator constantly is seeking to isolate the findings and conclusions of thousands of other research workers, but finds it impossible to keep abreast of current thought, even in restricted fields. He feels, however, that the difficulty is not so much that there is an undue amount of publishing in view of the extent and variety of present day interests, but rather that publication has been extended far beyond present ability to make real use of the record. He finds that professionally the methods of transmitting and reviewing the results of research are old and inadequate. The real heart of the matter of selection, he feels, goes deeper than a lag in the adoption of mechanisms by libraries, or a lack of development of devices for their use. The ineptitude in getting at the record is largely caused by the artificiality of systems of indexing. He points out that when data of any sort are placed.in storage, they are filed alphabetically or numerically and the information is found by tracing down from subclass to subclass. It can be in only one place unless duplicates are used. Having found an item, he says, one has to emerge from the system and re-enter on a new path. He contends that the human mind does not work that way. It operates by association and man cannot hope to duplicate fully this mental process artificially, but he certainly ought to be able to learn from it. The first idea, therefore, to be drawn from the analogy concerns selection. He predicts that selection by association rather than indexing may yet be mechanized. In the future, Bush believes, the problem of classification will be met by arranging for the classification of every article and report prior to

$$
{ }_{11} \text { Op. cit., p.79. }
$$

publication according to some prearranged system. ${ }^{32}$

Research Assistance and the Scholar. It is important to know what special services the scholars would like to have in addition to the materials they want available. Some libraries have provided research assistance to the scholars; however, the success or failure of such assistance has depended on the local situation. Altick believes that on the staff of every large research library there should be at least a few persons whose major training has been not in library science, but in the various fields of the humanities and the social sciences. These people should have had not only extensive personal experience in research, but what is even more important they should be expected to keep up with all the latest developments in their fields, such as the appearance of new reference works and bibliographies. ${ }^{33}$

Testimony has been presented earlier to the effect that the literature in any one subject is getting to be so vast that the researcher can keep up with it only with the greatest difficulty. Henry Gilman, professor of organic chemistry, Iowa State College, feels that the scientist wants to be liberated from the increasing drudgery of literature searches. ${ }^{34}$ Pundsack, on the other hand, believes that a research man should make his own literature surveys, ${ }^{35}$ and Edward G. Lewis, associate professor of political science, University of Illinois, feels that the political scientist of some experience does not expect help on the body of his material, but on the allimportant and often elusive peripheral details. He thinks that the reference librarian should be the one to be called on for this type of assistance, as well as

\footnotetext{
32 Science, the Endless Frontier (Washington: Govt. Print. Off., 1945), pp.112-15.

${ }_{34}^{33} O P$. cit., p.377.

34 "What the Scientist Expects of the Librarian,"

$C R L$. VIII (1947), 331 .
} 
to keep the scholar informed about new bibliographies. ${ }^{36}$

Among the services that Pundsack and others would like to have are abstract bulletins published by the library. These bulletins should contain abstracts from current periodicals, patent abstracts, and information about current acquisitions. $\mathrm{He}$ would also have the research library furnish some type of translation service by either sending the articles to an outside translator or by maintaining a staff which can translate. Finally, he would like to have research libraries circulate reference books, or put them on permanent loan to frequent users. ${ }^{37}$

Research libraries are admittedly complex. It is to be expected, therefore, that the user may need some guidance and training in their use. However, Fruton states that it is the responsibility of the scientist to know the library, and the responsibility of the library to make books easily available and to send regularly to the research user lists of new accessions in his general field of interest. ${ }^{38}$ Morse agrees with this position and states that the research man must know his way around the working library. Normally, he should not have to go to the card catalog, except to find a book in some branch of his subject that is relatively unfamiliar to him. ${ }^{39}$ Conway Zirkle, professor of botany, University of Pennsylvania, on the other hand, feels that the research man will have to be taught how to use the library. Few scientists realize, he believes, that library research is actually a form of scientific research, and therefore must be learned. ${ }^{40}$ W. F. Waldeck, director of Research and Development Division, Wyandotte Chemicals Corporation, notes that research projects almost invariably start with a survey of the available information, and

30 "The Political Scientist in the Reference Library," CRL, XIII (1952), 162.

${ }^{37}$ Op. cit., p. 164 .

38 Op. cit., p. 75 .

40 "Patterns of

Needs," in Penearch and Changing Library cit., p.17. that as much as one-third of the entire cost of research projects may lie in gathering and interpreting literature pertaining to the subject. ${ }^{41}$ As a corollary to being taught how to use the research library, Pundsack urges that the librarian of a research library prepare a written introduction to the library to give the user a background. ${ }^{42}$

The Scholar's Version of the Ideal Librarian. One of the most important ingredients of a successful library of any type is the librarian, and scholars have become very familiar with this professional collaborator in research. Altick finds, however, that as the library profession has grown more specialized and complicated, its members have lost touch, to some extent, with the people they serve. He urges that the best way of closing the gap is to encourage more librarians to have a broad training and a continuing interest in subject areas. He finds it especially regrettable that so many people in the top echelons of libraries have not had personal experience in humanistic research and he feels that with the best will in the world they cannot possibly see things as the scholar sees them. At the same time, he finds that too often the manner of library people, in dealing with their patrons, is exasperating. He points out that he is not speaking of department heads or other dignitaries, but of the people under them, the clerks, attendants, and assistants, with whom the scholar has the most frequent dealings. He feels that the habitual discourtesy or indifference of certain library people when dealing with patrons, be they freshmen or worldfamed scholars, gives substance to the impression held by some that libraries are operated not to be of all possible service to readers, but for the private convenience of the management. ${ }^{43}$ Millet states that librarians rate the impor-

\footnotetext{
41 "Research Management Looks at the Library," Special Libraries, XL (1956), 22.

42 Op. cit., p.166.

${ }^{43}$ Op cit., pp.376, 377.
} 
tance of their jobs and examine their salary scale in the light of the size of book collections, number of employees, and total expenditures; they put little emphasis on economy. ${ }^{44}$

Jacques Barzun, Columbia University, observes that the first virtue of the librarian should be that of attentiveness, and, his second virtue, general knowledge. Regarding the second virtue-general knowledge-Barzun believes that the ideal would be to have no distinctions whatever between librarians and scholars: scholars should be librarians and librarians should be scholars. Together, they should emphasize the using of books. ${ }^{45}$ Hartwell maintains that the bond that should hold scholars and librarians together is their love of books. The librarian, like the scholar, should be a bibliophile. As a custodian of books, he believes, the librarian is custodian of civilization, of the cultural heritage which is the basis of civilized living. In consideration of these principles, Hartwell expects from the librarian a full knowledge of the resources of the library and of its catalogs and indexes. A librarian, he states, should have knowledge of books as well as of library organization, and the research librarian should be a scholar-librarian, for only such a person has a complete understanding of the needs of scholars. Alternatively, Hartwell believes, each research library should have, in addition to the librarian, a director of research and a research staff who would play vital roles in the library and its organization.

Hartwell makes these statements with firmness and conviction. However, when discussing the ordering of books he reverses his original opinions by proclaiming that it is far better for the scholar to have good books than good librarians. In fact, he contends, if the books are available and there is some means of get-

14 Loc. cit.

45 "The Scholar Looks at the Library," $C R L$, VII (1946), 115-16. ting at them, then the librarian need be little more than an attendant. He also criticizes librarians by pointing out that the feeling of proprietorship is the most common failing of librarians. The danger sign is the term "my library." 46

Speaking for scientists, Gilman first suggests the expectation of adequate, efficient, and courteous service. In addition, the librarian should have thorough familiarity with indexing systems, classification, interlibrary loans, photostating and microfilm problems, the publishing habits of domestic and foreign periodicals, sources of manuscripts, reprints, and patents. The librarian should also be capable of reading German, French, and Russian. He should have sufficient scientific background to know technical language and nomenclature, and above all, he should know at all times where his books are and should know how to supplement catalog information with suggestions of likely places and people capable of supplying information not conventionally accessible. Gilman continues that in addition to knowing where his books are the librarian should help his patrons by guiding and instructing them in one manner or another to locate material quickly and confidently without too much trial and error. A librarian who is capable of all of this should have compensation not only in terms of money, but in rank and prestige commensurate with the great importance and dignity of his work. ${ }^{47}$

Librarians should find encouragement in the observations of Hart. ${ }^{48}$ Not only is the library essential for the great university, he notes, but qualified reference librarians are indispensable in guiding users to the contents of the collections. Hart shows by example how librarians and scholars working together assist the researcher in the completion of projects.

The Scholar Predicts the Future of

${ }^{46}$ Op. cit., pp.91-93.

47 Op. cit., pp.329, 332.

48 "Search and Research: The Librarian and the Scholar," $C R L$, XIX (1958), 365-74. 
Research Libraries. No one can predict with certainty what the future holds for research libraries. However, there are certain tendencies that are evident, and one scholar has availed himself of the opportunity to comment.

Gottschalk feels that the foremost influence upon the university research library is likely to be the international tension to which it will have to adjust itself. He feels that one of the important effects on scholarship of prolonged animosities will be an intensification of the national spirit. Therefore, the university library of the future will be able to devote less and less space to the fewer and fewer scholars who will be interested in rare books and other out-of-print materials. Most research libraries will become more definitely than they are now, collections of reference, teaching, serial, and recent titles, and will become less concerned than now with special collections made up largely of rare and out-of-print books.

Gottschalk offers a plan to cope with these predicted developments. He suggests that the scholar in American universities become less dependent upon the university library and more willing to make his own special collection for each of his scholarly projects in turn. In order to facilitate this, the funds now made available to librarians by universities and foundations for special collections should go directly to the working scholar. Furthermore, the libraries should break up the special collections that are not in active use and make the rare and out-of-print materials in them available for long periods, either by loan or purchase, to the scholars who actually need them. The advantages to the scholar of this proposal would be that he would not have to use microfilms or photostats, but would have the use of the original. The advantages to the library would be the release of space that is now occupied by seldom-used works. It would reduce the number of visitors, of microfilm requests, and of interlibrary loans. Finally, according to Gottschalk, this plan would diminish the cost and difficulty of policing rare and costly items. ${ }^{49}$

Jones adds the admonition that as government pours its millions into science and the social sciences, neglecting the humanities, we must, if we are not to throw our whole cultural life into the discard, pour more money rather than less into university research libraries, for they are the laboratories and the refuge of the scholar, the humanist, the writer, and the philosopher. ${ }^{50}$

Conclusions. The preceding statements have revealed no startling new suggestions concerning scholars' relations to the research library. However, the one truth that seems abundantly clear is that what may be true of one type of research library may not be true of another, and what may serve one scholar does not necessarily serve another. Therefore, it is the librarian's first duty to define the policies of his library based on the general aims that have evolved.

Special libraries and special collections present many problems. However, since the purposes and aims of special libraries and special collections are usually narrower and more clearly defined, their problems are relatively simple compared to those of a university library. The university research library must, on the other hand, serve the entire range of scholarship. There are conflicting demands and needs to be met. The humanists and social scientists would like to have everything that is in print; the natural scientists want less of the older historical materials and would rather have current periodicals and books. In fact, they would rather have librarians spend more time abstracting articles and making accession lists than caring for old and rarely used materials.

In respect to the rapid growth of holdings, the humanists and social scientists

49 Op. cit., pp. $49,50,51,54,57$.

50 Op. cit., p. 21 . 
suggest curbs by assigning priorities to purchases. There was no suggestion from them to reduce the amount of publishing such as proposed by the natural scientists. The suggestion that publishers issue only what is worth publishing is courageous, but not realistic. Who is to decide what is not worth publishing? The answer for libraries lies in selection after publication. A positive approach to coverage urges that authors abstract or summarize their contribution to the literature. This would enable the user to get an overview of the literature in his field and would conserve space in the library.

The catalog represents an area of difference of opinion between humanists and social scientists as opposed to natural scientists. The former want as detailed a catalog as is possible with complete descriptions of the items cataloged and with extensive subject headings. The latter claim that many subject headings are unnecessary, and that a mere finding list would be satisfactory.

The problem of research assistance is rather confused. There is disagreement among all groups of scholars, probably based on the work methods of the individuals involved. Some scholars appear to be independent workers, others would like to be relieved of some of the tedious chores that are part of scholarly research. There is no doubt, however, that assistance of some kind should be available. The form and nature of the services supplied are, of course, circumscribed by the budgets as well as the abilities and limitations of the librarians in question. So far as the future is concerned, research libraries will probably continue to collect everything they deem necessary to preserve the record and to enhance scholarship in the fields in which their institutions have a stake. On the other hand, improved techniques will take the path toward speedier handling, toward improved methods of reduction of space needs through reduction in bulk, and toward improved methods of reproduction of materials for wider dissemination and use.

Scholars will be able to depend on the librarians for their future needs because in the past it has been the librarians who, through diligent and conscientious effort, and often in the face of determined opposition by scholars and administrators, have achieved whatever improvements have been made.

\section{Standards Reprints Available}

Reprints of the "Standards for College Libraries" which appeared in the July 1959 issue of $C R L$ are now available from the ACRL office, 50 East Huron Street, Chicago 11. Single copies will be mailed free on request. For orders of five or more reprints the price per copy is twenty cents. Prepayment will expedite delivery of orders and it is requested that cash or check accompany orders if possible. 